Tér és Társadalom 16. évf. 2002/4. 109-128. p.

Tér és Társadalom

XVI. évf. 2002

4: $109-135$

\title{
KITEKINTÖ
}

\section{TERÜLETFEJLESZTÉSI ÉS ÉRTÉKELÉSI RENDSZER AUSZTRIÁBAN ${ }^{1}$ \\ (System for Regional Development and Evaluation in Austria) \\ FINTA ISTVÁN}

Kulcsszavak:

területrendezés területi programozás regionális politika értékelési jelentés jogi szabályozás

Ausztriában a tartományok számára jelentös döntési jogosítványokat biztositó szövetségi berendezkedés ellenére a területfejlesztés rendkivül csekély mértékben jelenik meg azon a szinten, ahol a legerösebbnek kellene lennie, vagyis a tartományok szintjén. A tanulmány ezen a szinten ismerteti a területfejlesztés rendszerét, s mutatja be a róluk készült jelentést.

\section{Bevezetés}

A magyar területfejlesztés törvényi szabályozása óta eltelt idő lehetőséget kínál arra, hogy a jogalkotó szembesülhessen mindazokkal a hatásokkal, amelyek akár elönyösen, akár hátrányosan befolyásolták a szabályozni kívánt életviszonyokat, vagyis a területi fejlődés komplex probléma rendszerét. A kitúzött célok és a gyakorlatban megvalósult eredmények összevetésére az Európai Unió tagállamainak többsége figyelmet fordít, melynek tapasztalatait és a területfejlesztés és tervezés további irányaira hatást gyakorló következtetéseket különbözö időszakok szerint, különböző felépítésben ún. jelentésekben tesznek közzé. Hazánkban a területfejlesztésröl szóló törvény elöírja a kormány kétévente történö beszámolási kötelezettségét az ország területi folyamatainak alakulásáról és a területfejlesztési politika érvényesüléséröl a parlament számára. A beszámolók fejlesztéséhez, a magyar területfejlesztés átfogó értékelésének kialakításához talán hozzájárul az Unió tagállamainak, különösképpen a hozzánk bizonyos tekintetben hasonló és velünk szomszédos ország - Ausztria - területfejlesztési folyamatait vizsgáló dokumentumainak áttekintése és értékelése.

A területfejlesztési és értékelési rendszer elemzésének alapjául elsősorban az Osztrák Területrendezési Konferencia által készitett „Kilencedik területrendezési jelentés" szolgált, ezen túl azonban segítséget nyújtott minden olyan könyv és tudományos folyóiratban megjelent cikk, amely kiegészítette a jelentésben található információkat és ezáltal teljesebbé tette az osztrák rendszerről kialakítandó képet.

A területi folyamatok értékeléséról szóló jelentés az osztrák területfejlesztési rendszer bizonyos szintủ ismeretét természetesnek tekinti. Mindemellett bemutatja az osztrák jogi szabályozás rendszerét, az egyes területi szintek feladatait, azonban 
ezek az információk nem egységesen és összefüggően, hanem a jelentés különböző részeiben találhatók meg. Ezért célszerủnek tünt a területfejlesztésre vonatkozó mindazon - minimálisan szükséges - ismeretek rendszerbe foglalása, amelyek nélkülözhetetlenek az értékelés megértéséhez. A területfejlesztés jogi szabályozása, tervezési gyakorlata, fogalomhasználata területén az osztrák és a magyar megoldások között jelentös eltérések találhatók. Mindenekelött ezen eltérések rövid bemutatására szuikséges sort keríteni.

\section{Fogalmi eltérések}

$\mathrm{Az}$ ausztriai területi folyamatokkal foglalkozó szakirodalom, de legföképpen a jogi szabályozás meglehetôsen ritkán használja a területfejlesztés kifejezést. A két leggyakrabban előforduló szakkifejezés a területrendezés és a területi tervezés. A magyar jogi szabályozás és gyakorlat szerinti területfejlesztés tartalma inkább az osztrák területi tervezés fogalmi köréhez áll közelebb, de a területrendezés jelentéstartalma sem azonos a magyar értelemben vett területrendezéssel. A területi tervezés Ausztriában csupán egy bizonyos része, részhalmaza a területrendezésnek. „A területrendezés a közjogi testületek köz- és magánjogi intézkedéseinek (aktusainak) összessége, melyek arra irányulnak, hogy a terület egésze meghatározott politikai célkitűzéseknek megfelelően alakuljon. Ez vonatkozik a gazdasági, szociális, kulturális viszonyokra egyaránt. A területrendezés ezen túl nemcsak elóre tervezett földhasználatot jelent, hanem minden olyan, a térre vonatkozó és a térre hatást gyakorló intézkedést, amely az adott terület alakulására valamilyen hatást fejt ki." (Schindegger 1999, 32) „Összegezve megállapítható, hogy a területrendezés feladata egyrészt a társadalom és a gazdaság területi igényei, másrészt a meglévő területi potenciálok közötti kiegyenlítés megvalósítása." (Schindegger 1999, 34)

A területrendezés tehát olyan tág kategória Ausztriában, amelybe belefér a mi fogalmaink szerint értelmezett területfejlesztés-rendezés, területi tervezés, sőt a regionális politika is. A regionális politika - szövetségi szinten - meghatározó szerepkörrel rendelkezik, ugyanis „Területrendezési politika alatt szövetségi szinten már több mint 20 éve gyakorlatilag és kizárólag regionális politikát, mindenekelött pedig regionális gazdaságtámogatást értenek. Ez a politika az olyan hátrányos helyzetü vidékekre korlátozódott, mint a periférikus vidéki régiók (turizmus nélkül) és a hagyományos iparvidékek." (Schindegger 1999, 123) A korábbi osztrák regionális támogatási rendszerhez képest persze jelentős változásokat hozott a tagságot követő strukturális alapok rendszere, amely megteremtette a többéves tervezést, illetve a programozást, a projektek közös finanszírozását, valamint az elöre meghatározott értékelési rendszer alapjait.

A szövetségi szintú területrendezés értelmezése elsősorban azért tủnik fontosnak, mert alapvetően ez az a terület, amely megfelel a magyar területfejlesztés - gazdaságfejlesztési indíttatású - fogalomrendszerének. Mindamellett akár a jogi szabályozás, akár a tervezés szemszögéből tekintve, a területfejlesztési tevékenység jelentősége nem túl nagy, a területrendezésen belül hozzávetőleg egyharmad arányt 
képvisel. Ezt elsősorban azzal magyarázzák, hogy fontosabbak azok a technikai normák, amelyek azt mondják meg, hogy hol és milyen ipartelep épülhet, illetve merre vezessen az autópálya új szakasza, mint egyes gazdasági problémák kezelése, mivel azok jelentös részét egy jól müködő gazdaság amúgy is orvosolja. Magyarországon ezzel szemben fontosabb kérdésnek tủnik az, hogy hogyan létesül ipari üzem vagy autópálya, mint az, hogy milyen technikai szabályok vonatkozzanak azokra.

Az osztrák és a magyar viszonyok között nem csupán a gazdasági fejlettség okoz jelentős különbségeket, hanem az államberendezkedés és az ezzel kapcsolatos jogi szabályozás is. Ausztria szövetségi állam, ezáltal a tartományok igen jelentös autonómiával, önálló szabályozási jogosítványokkal rendelkeznek. Ezt az önállóságot csak tovább erösíti az a tény, hogy - a szomszédos Svájccal vagy Németországgal ellentétben - Ausztriának szövetségi szinten nincs területrendezési törvénye. A területrendezés jogi szabályozása és gyakorlati végrehajtása így a tartományok szintjén zajlik. A tartományok mindegyike rendelkezik területrendezési törvénnyel, szemben például Németországgal, ahol ezt a kifejezést kizárólag a szövetségi szint számára tartják fenn, alatta tartományi, regionális tervezésröl beszélnek.

Az osztrák alkotmány szerint egy terület lakó és ipari célú beépítése, illetve a beépítetlen területek megtartása, az ezekre vonatkozó jogalkotási és végrehajtási tevékenység akkor tartományi ügy, ha nem különleges jelentőségü vasúti, erdő, hegy vagy vízügyi kérdésről van szó, ellenkezỏ esetben, illetve ha a törvény kifejezetten ezt írja elő, szövetségi hatáskörbe tartozik.

Tartományi szinten tehát kilenc, egymáshoz igen hasonló területrendezési törvény megalkotására került sor, elsősorban az ötvenes, hatvanas években. (Tartalmilag azóta jelentősen megújultak, különösen a kilencvenes években az EU csatlakozás küszöbén.) A törvények konkrét elöírásokat nem tartalmaznak a területi tervezésre vonatkozóan, hanem keretszerủen szabályozzák a területrendezés általános és különös normáit. A törvények középpontjában a helyi szint feletti tervezés eszközrendszere, illetve annak felépítésę áll. Ezen túl - talán a legrészletesebben szabályozott terület - az önkormányzatok helyi tervezésének megvalósítására vonatkozó kötelezettségeit foglalják magukban.

A tervezés - és ezzel együtt a területfejlesztés - konkrétan, a különböző szintư programokban manifesztálódik. A programok rendszerének ismertetése előtt szükséges rávilágítani arra a kérdésre, hogy mely szervek, milyen felhatalmazás alapján jogosultak, illetve kötelezettek a programok elkészítésére.

Legegyszerübb a helyzet a programozás legalsó szintjén, vagyis a helyi önkormányzatok esetében. Az erre vonatkozó kötelezettségüket a felsőbb szintü jogszabályok keretjelleggel szabályozzák. Középszinten, vagyis a tartományok szintjén, egymástól meglehetősen eltérỏ programozási gyakorlattal találkozhatunk. Ugyanakkor, minden tartomány esetében közös vonás az, hogy a regionális programalkotás joga az önkormányzati szövetségeket illeti meg. Továbbá, az egyik fö irányzat szerint, mely Salzburg tartományban alakult ki, az önkormányzati szövetségek átruházták a programalkotás jogát a tartományi kormányzatra, igaz, az így kialakí- 
tott program csak a tartományi rendelet formájában válik jogilag kötelezóvé. AlsóAusztriában egy teljesen más megoldást követnek, amely a tartományi kormányzat támogatása mellett, ún. kisrégiós szövetségek által alkotott kisregionális fejlesztési koncepciók elkészítését eredményezi. Ezek a koncepciók kötelező jogi erōvel nem rendelkeznek.

A tervezés talán a nemzeti szinten a legérdekesebb. (A teljes tervezési rendszert a 1. táblázat mutatja be.)

\section{TÁBLÁZAT}

Az osztrák területi tervezés rendszere

(Spatial Planning System in Austria)

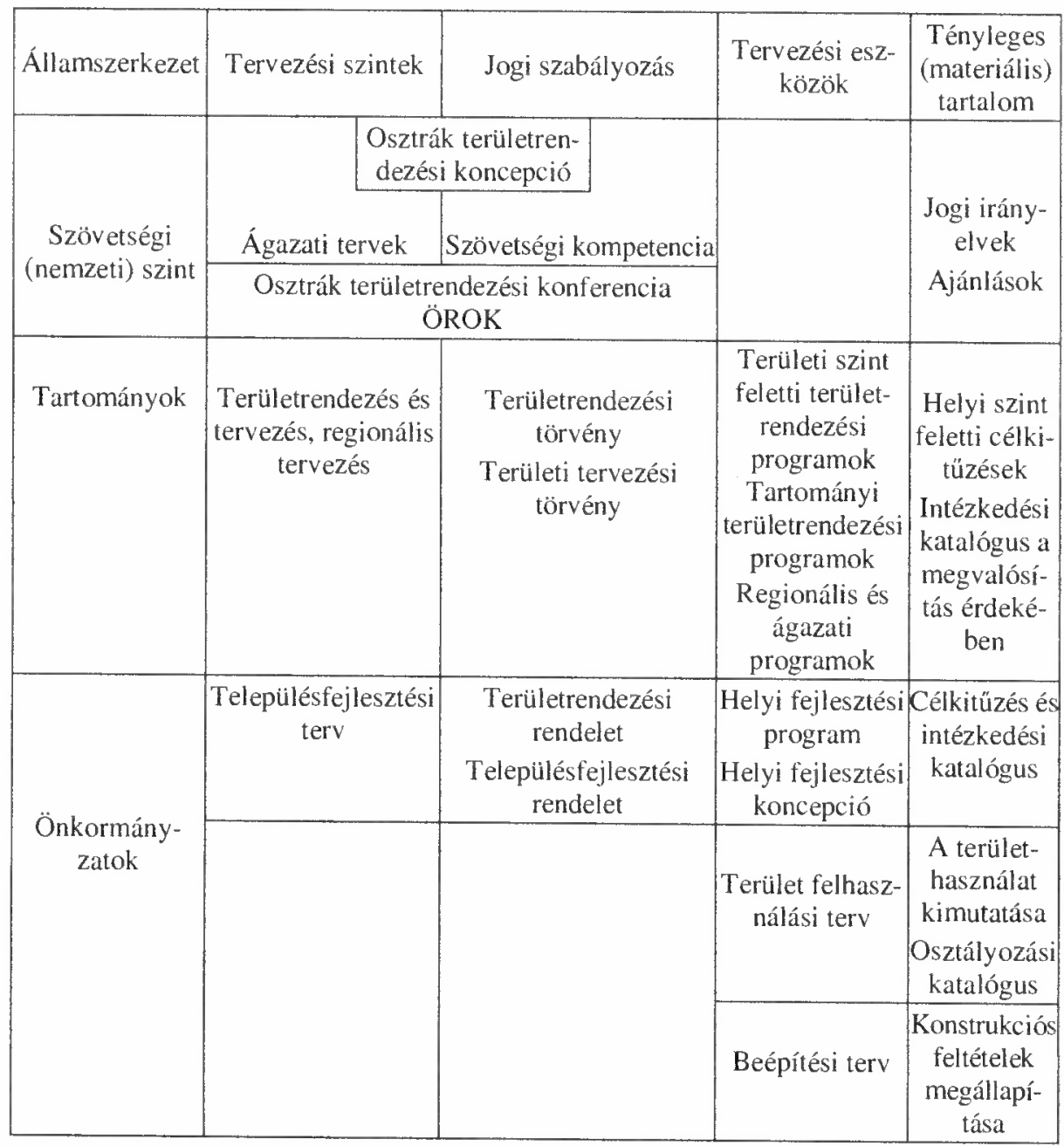

Forrás: Deutsch-Österreches Handbuch der Planungsbegriff. 2001, 111. o. 
Nemzeti szintủ törvény hiányában a programalkotás ún. ,gentlement’ agreement” (Semsroth-Dillinger 2002, 52) alapján történik az önkormányzatok, a tartományok és a szövetségi kormányzat között. Ennek az együttmüködésnek a legfontosabb színtere az Osztrák Területrendezési Konferencia, melynek önálló menedzsmentjéröl a későbbiekben még szó esik.

A területi szintủ programok hierarchiájában a legfelső szinten a tartományi terïletrendezési program áll. Ez a program részint meghatározza a régiók regionális programjainak, részint pedig az egyes ágazati programok témáinak minimális tartalmi elemeit. A tartományi területrendezési programokban többnyire együttesen szerepelnek konkrét célkitüzések, a területi tervezést érintő megállapítások, valamint általános jogi irányelvek a további, ,alárendelt” tervek számára.

A tartományi területrendezési programokat a tartományi kormány fỏhatóságai készítik el. A tervezetet megküldik a kormány illetékes minisztériumainak, az érdekképviseleteknek, a szomszédos tartományoknak, a regionális tervezési szövetségeknek és az önkormányzatoknak.

Ezekkel a programokkal szemben elsősorban olyan kritikák hangzanak el, hogy funkciójuk alapvetően rendezési jellegü, és csak ritka esetben fejtenek ki a tervezési folyamatra irányuló, azt előmozdító hatást.

\section{1. ÁBRA}

Ausztria közigazgatási felosztása (2357 önkormányzat, 99 járás, 9 tartomány) (Administrative Units in Austria; 2357 Local Governments, 99 Districts, 9 Lands)

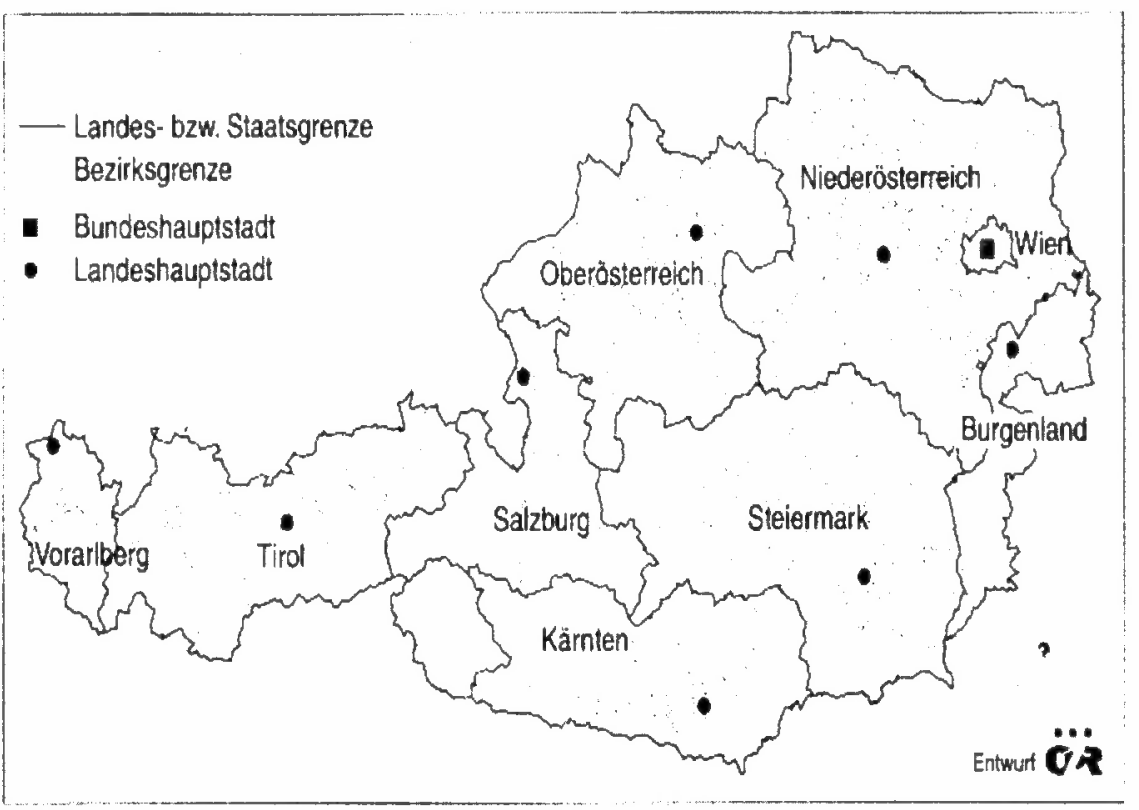

Forrás: Schindegger 1999. 
A regionális programok jellemzését megelőzően szükségesnek tünik bemutatni azt, hogy Ausztriában mit értenek régión, mire is irányulnak valójában a regionális programok. A régiók területi meghatározása tekintetében a szomszédos országban, ha lehet, még inkább eltéró vélemények alakultak ki, mint hazánkban. A régió fogalmi elemének a homogenitást, illetve a hasonlóságot, valamint a funkcionális kölcsönhatást, összefonódottságot tekintik az osztrák szakemberek. További régióalkotó ismérv lehet szerintük a cél is (ez utóbbi elem fogja át - véleményük szerint - a strukturális alapok által támogatott célterületeket vagy pl. az Alpok-Adria régiót). A felsorolt ismérvek alapján Ausztriában - alulról tekintve - egyaránt régiónak tekinthetik például Waldviertel-t (a mi fogalmaink szerint kistérség), valamint felülről tekintve - magát Ausztriát, mint az Alpok régió vagy a Duna régió részét. E felfogásnak megfelelóen fóként az alábbi régiókat különböztetik meg az osztrák szakemberek: városrégiók, tervezési régiók (a NUTS 2-es szint teljesen megegyezik a tartományok határaival), gazdasági tipizálás alapján kijelölt régiók (1., 2., 3., 4. ábra).

\section{2. ÁBRA}

Városrégiók Ausztriában

(Urban-regions in Austria)

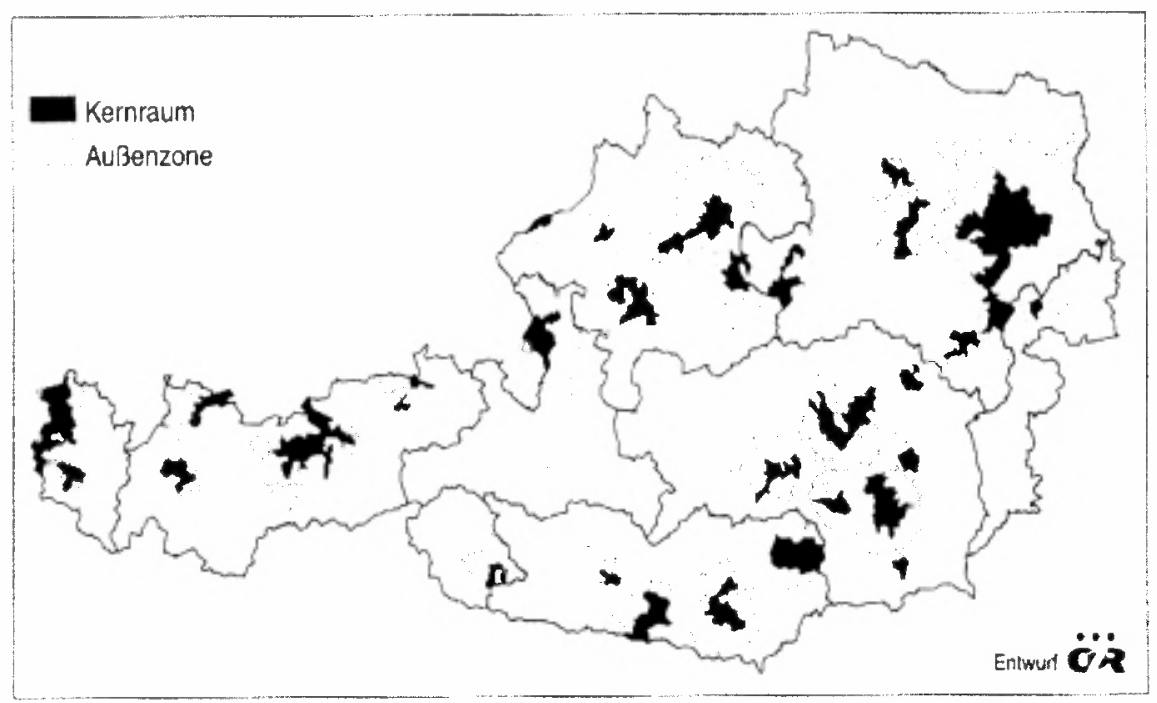

Forrás: Schindegger 1999.

A régiók Ausztriában semmilyen szervezeti egységgel nem rendelkeznek, és ennek megfelelően politikai érdekképviseleti rendszerük sincs. (A régió - mint területi egység - ilyetén történö, lágy felfogása hasonlít a mi törvényi szabályozásunk területfejlesztési társulásokra vonatkozó rendelkezéseihez. A területi egység mérete nálunk az önkormányzatok elhatározásától függ, míg Ausztriában valamilyen objektív - homogenitásnak és a funkcionális kapcsolatoknak megfelelö - ismérv alapján alakul ki egy területi egység.) 


\section{3. ÁBRA}

NUTS 2-3 szint Ausztriában

(NUTS 2 and 3 Levels in Austria)

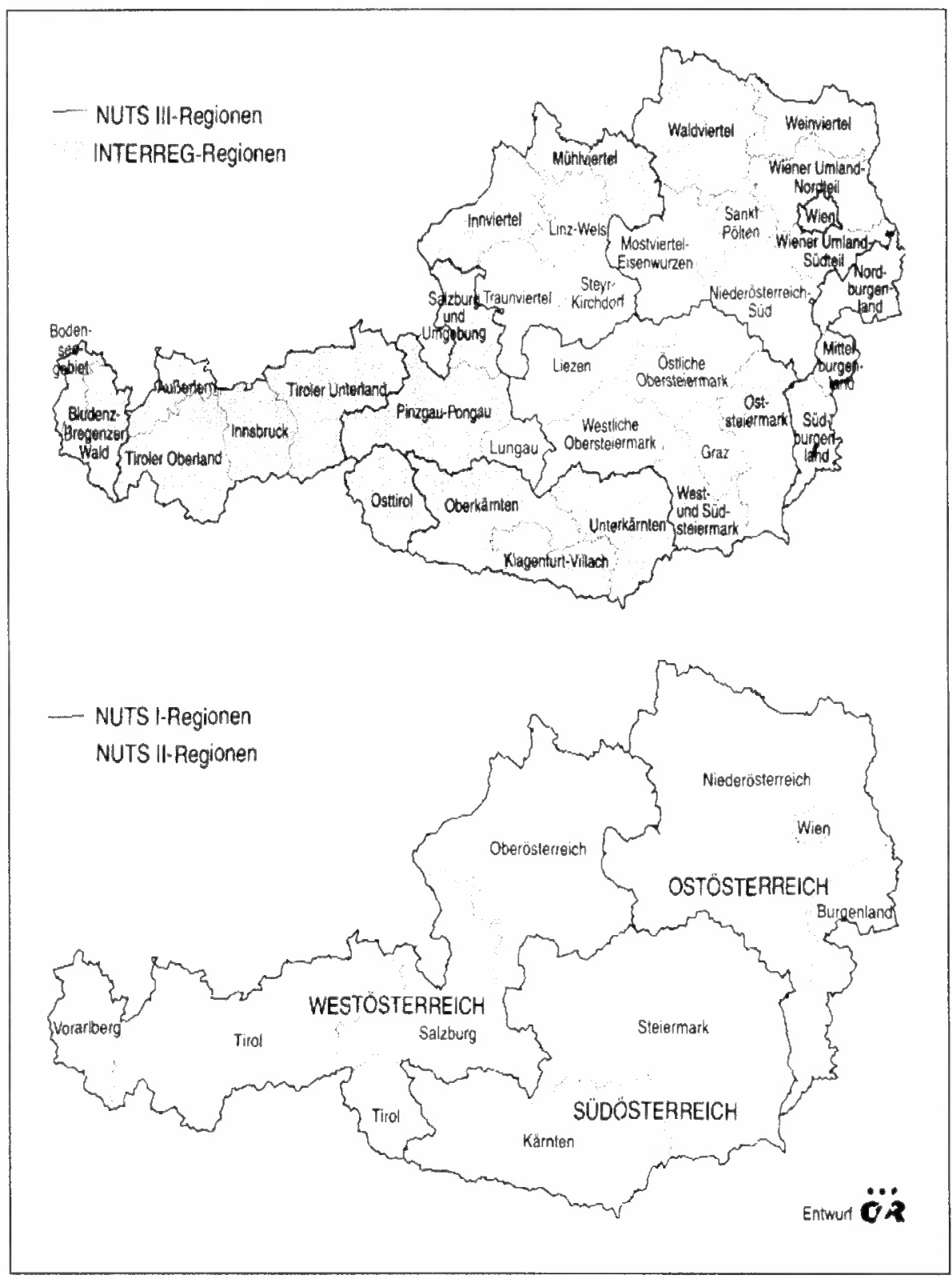

Forrás: Schindegger 1999. 


\section{4. ÁBRA \\ Gazdasági régiók Ausztriában \\ (Economic Regions in Austria)}

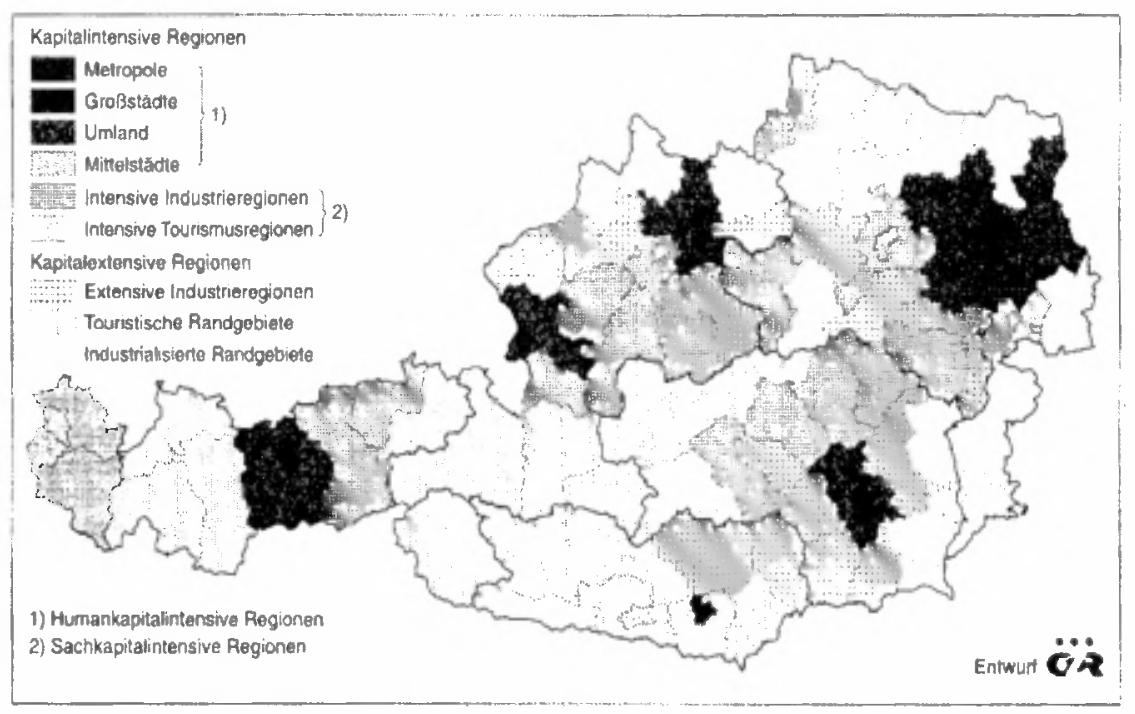

Forrás: Schindegger 1999.

A regionális területrendezési és fejlesztési programok jórészt az önkormányzatí szinten elkészítendő rendezési tervek számára tartalmaznak előírásokat. A konkrét rendelkezések például az infrastruktúra kiépítésére, az ún. alkalmassági területek kijelölésének szempontjaira vonatkoznak, az egyes ágazatok (mezőgazdaság, ipar, turizmus, nyersanyag kitermelés) igényeit figyelembe véve.

A regionális tervek kidolgozásának feladata a tartományi kormány hatóságainak hatáskörébe tartozik. Ugyanakkor a tényleges tervezési tevékenységet igen gyakran más szervezetek látják el, a hatóság és az adott szervezet között létrejött szerzódés alapján (kiszerzỏdés). Néhány tartományban viszont a regionális tervek kídolgozásában - regionális tervtanács formájában - maguk az önkormányzatok is részt vesznek. Ilyen esetekben a tervezési munka sikerességéhez - az osztrák szakértők véleménye szerint - szükséges az önkormányzatok nagyfokú egyetértési készsége, valamint identitás tudata.

A regionális fejlesztési programok elkészítését valamennyi tartományi terủletrendezési törvény elöirányozta, azonban ezideig ennek csupán Steiermark tett eleget ő sem teljes egészében -, amikor kidolgozta a Graz és Graz környékére vonatkozó regionális fejlesztési tervet (Neunter Raumordnungsbericht 1999). Burgenland 1994-ben a tartományi területrendezési programja útjản határozta meg regionális területfejlesztési programját, Salzburg pedig tovább bővítette a regionális programja által érintett területeket, jóllehet ez a tevékenység inkább csak a korábbi területrendezési törvény módosításában merült ki. Tỉrol többé nem készít regionális programot, ugyanis az utolsó program - amely Wipptal kisrégióra irányult - 10 esztendö 
után eredménytelenül ért véget. Ezután csak ún. helyi szint feletti zöldzónákra, valamint különleges mezögazdasági területekre vonatkozóan készítenek fejlesztési terveket. A tiroli gyakorlatnál még rosszabb a helyzet Voralbergben, ahol még soha nem készítettek regionális programot. Összegezve megállapítható, hogy egész Ausztriában a jogilag elfogadottnak tekinthetö regionális fejlesztési tervek az összterület mindössze $45 \%$-át, a lakosságnak pedig csupán 43\%-át érintik (2. táblázat).

\section{TÁBLÁZAT}

A tartományi és a regionális tervekkel érintett területek és lakosság (Territories and Population Covered by Land and Regional Plans)

\begin{tabular}{|c|c|c|c|c|c|c|c|c|}
\hline \multirow{2}{*}{$\begin{array}{l}\text { Tarto- } \\
\text { mányok }\end{array}$} & \multicolumn{2}{|c|}{$\begin{array}{l}\text { Tartományi össze- } \\
\text { sítés }\end{array}$} & \multicolumn{2}{|c|}{$\begin{array}{c}\text { Tartományi } \\
\text { fejlesztési prog- } \\
\text { ram (megvalósí- } \\
\text { tott \%) }\end{array}$} & \multicolumn{4}{|c|}{$\begin{array}{c}\text { Ebbỏl megvalósított regionális tervekkel } \\
\text { érintett terület és lakos }\end{array}$} \\
\hline & $\begin{array}{c}\text { Terület } \\
\mathrm{km}^{2}\end{array}$ & $\begin{array}{l}\text { Lakos } \\
1991\end{array}$ & Terület & $\begin{array}{l}\text { Lakos } \\
1991\end{array}$ & $\begin{array}{c}\text { Terület } \\
\mathbf{k m}^{2}\end{array}$ & $\begin{array}{l}\text { Lakos } \\
1991\end{array}$ & $\begin{array}{c}\text { Terulleti } \\
\text { részesedés } \\
\%\end{array}$ & $\begin{array}{c}\text { Lakosság } \\
\text { részesedése } \\
\%\end{array}$ \\
\hline $\begin{array}{l}\text { Burgen- } \\
\text { land }\end{array}$ & 3966 & 270880 & 100 & 100 & 203 & 7828 & 5 & 3 \\
\hline Karintia & 9533 & 547798 & & & 3605 & 326919 & 38 & 60 \\
\hline $\begin{array}{l}\text { Alsó- } \\
\text { Ausztria }\end{array}$ & 19174 & 1473813 & & & 9867 & 988003 & 51 & 67 \\
\hline $\begin{array}{l}\text { Felső- } \\
\text { Ausztria }\end{array}$ & 11980 & 1333480 & 100 & 100 & & & & \\
\hline Salzburg & 7154 & 482365 & 100 & 100 & 6872 & 474051 & 96 & 98 \\
\hline $\begin{array}{l}\text { Steier- } \\
\text { mark }\end{array}$ & 16388 & 1184720 & 100 & 100 & 15810 & $\begin{array}{r}1155 \\
194\end{array}$ & 96 & 98 \\
\hline Tirol & 12648 & 631410 & & & 1531 & 127066 & 12 & 20 \\
\hline Voralberg* & 2601 & 331472 & & & 137 & 264453 & 5 & 80 \\
\hline Bécs & 415 & 1539848 & 100 & 100 & & & & \\
\hline Ausztria & 83858 & 7795786 & 48 & 62 & 38025 & 3343514 & 45 & 43 \\
\hline
\end{tabular}

* Voralbergben regionális program ugyan nem készủlt, de a Rajna völgy és a Walgau zöldzónáira vonatkozóan rendelkeznek település szint feletti programmal.

Forräs: Neunter Raumordnungsbericht 1999.

A fenti adatok meglehetösen elszomorítóak lehetnének, ha az osztrák régiókat a mi regionális beosztásunkkal azonosítanánk. Tekintettel arra, hogy az ausztriai régiók inkább a mi kistérségeinknek felelnek meg, szomszédaink tervezési aktivitása nem tekinthetö olyan tragikusnak, bár számszerüleg valószínüleg alatta marad a magyar kistérségek által készített fejlesztési koncepciók mennyiségének.

Több tartomány rendelkezik önálló ágazati programokkal is. Ezek az ágazati, vagy szakprogramok föként a turizmussal, a hulladék feldolgozással, lakásügyekkel, a bevásárlóközpontokkal, illetve a környezetvédelemmel foglalkoznak, és alapvetóen technikai normákat tartalmaznak.

A különböző programok lényegi vonásainak bemutatását követően érdemes tisztázni azt, hogy mi is a regionális politika és a regionális, illetve az általában véve vett területi programozás egymáshoz való viszonya.

Az osztrák szakemberek véleménye szerint a területrendezés és a regionális politika összetartozó fogalompáros, vagy legalábbis azoknak kellene lenniük. Ausztriá- 
ban mind a területrendezési, mind pedig a regionális politika az utolsó 40 évben mintegy anyagi kényszerüségböl fejlödött ki (Schindegger 1999, 95). Ezek a politikák nem egy államilag meghatározott célrendszer szerves részeként fejlődtek, hanem a politikai szükségszerüségböl nöttek ki. Bár a regionális politika legfontosabb feladata (Ausztriában is) a gazdaság fejlesztése, ez a funkció a kormányzati szint alatti területrendezés rendszerében (tartományi törvények, különbözö szintü programok) nehezen ismerhető fel. Így Ausztriában, összességében tekintve, a regionális gazdaságpolitika olyan fragmentált rendszert képez, amelyben sem a területi tervezés, sem a területi szintekre szétdarabolt regionális politika - érdemi intézkedések hiányában - nem játszik komoly szerepet (Schindegger 1999, 96). Ezt a széttagolt rendszert az Osztrák Területrendezési Konferencia hivatott összefogni, melynek keretében a helyi, tartományi, nemzeti szereplök igyekeznek meghatározni a gazdaságfejlesztés és támogatás irányait. Ez az irány a hatvanas években a hagyományos iparvidékek és a perifériális régiók fejlesztését célozta meg. A nyolcvanas évek kezdetétỏl a legfontosabb cél az egyes régiók belsỏ erőforrásaira támaszkodva, az innováció erősítése, szerkezetváltás a hagyományos iparvidékeken, a minőségi munkaerỏ arányának növelése stb. volt. Ezt a programban részt vevő hét tartomány, illetve az állam fele-fele arányban támogatta. A kilencvenes években a támogatások a technológia-transzfer, az innovációs központok, tudományos és ipari parkok megteremtésére irányultak.

$\mathrm{Az}$ uniós tagság jelentös változást hozott nem csupán a regionális támogatások céljainak meghatározásában, hanem az intézményrendszer felépítése tekintetében is. Ez elsősorban nem a fennálló rendszer reformját jelentette, hanem egy új szintet alakított ki a nemzeti, a tartományi, illetve a helyi szintek mellé. Az osztrák területrendezés és területfejlesztés - szakemberek által kívánatosnak tartott - rendszerét az 5. ábra szemlélteti.

Az osztrák területfejlesztési rendszer kilencedik jelentése és a vonatkozó szakirodalom alapján történỏ bemutatását követően sor kerülhet az említett jelentés - eddig nem tárgyalt - részeinek ismertetésére.

A jelentés az uniós csatlakozást követő három éves időszak területi folyamatairól számol be, amely 1996 januárjától 1998 decemberéig tartott.

A jelentés 5 fejezetre tagolódik, melyek közül az első a területrendezés jogi alapjaival foglalkozik (ezt a témát az előzőekben - a jelentésben foglaltaknál bővebben - érintettük).

A második fejezet az osztrák területfejlesztés fontosabb keretfeltételei és trendjei címet viseli. A fejezet első részében a jelentés az európai regionális fejlesztésröl szól, de itt sorolja fel Ausztria regionális politikája szempontjából problematikus területek között a tranzit forgalmat, a mezőgazdaságot és a bővítés folyamatát. Ez utóbbi területet a jelentés akként jellemzi, mint az olyan, alacsonyabb bérszintü és gazdasági teljesítő képességü országok csatlakozását, amelyek az EU liberális és nagyvonalú munkaerő és tőke politikája következtében megnövekedett harmonizációs problémát jelent egész Ausztria, különösen pedig a határ menti területek számára. (Ma már ismerjük a tagállamok nagyvonalú munkaerö és tőkepolitikáját.) 
Mindemellett a felsorolt problématerületek valóban rendelkezhetnek területi hatással (minden a térben valósul meg), ugyanakkor sokkal inkább tekinthetők speciális ágazati és nemzeti szintủ problémáknak.

5. ÁBRA

A területrendezési és területfejlesztési politika eszköztára

(The Instruments of Physical Planning and Regional Development Policy)

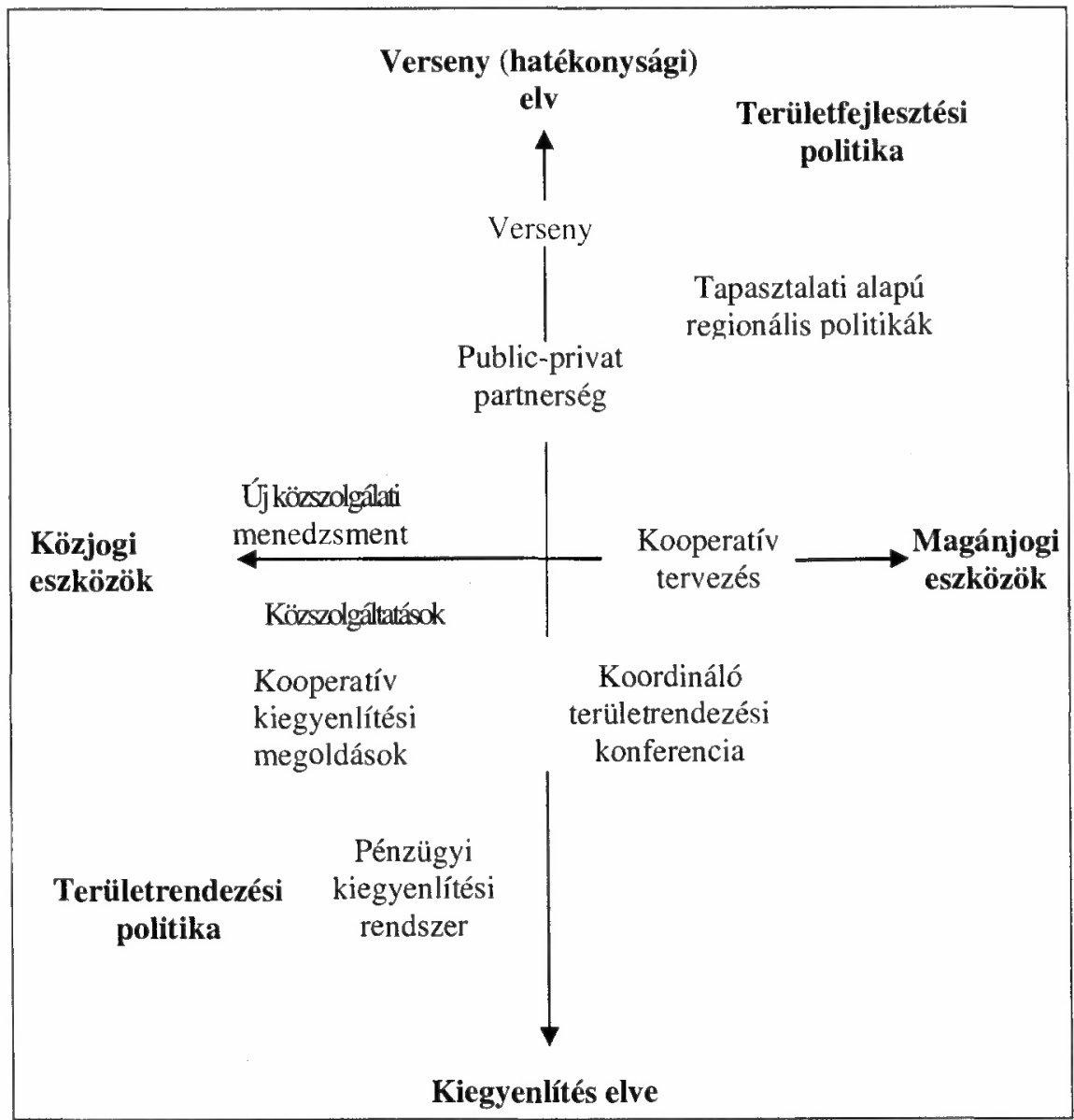

Forrás: Thierstein 2002.

A fejezet második része a hazai területfejlesztési programokhoz hasonlóan, helyzetelemzést ad a népességről, a háztartásokról és a lakáshelyzetről, a gazdasági fejlődésről, a foglakoztatásról és a munkanélküliség helyzetéről, valamint a közlekedési viszonyokról.

A népességi folyamatok vizsgálata során elemzik a szuburbanizációs hatásokat, a népesség országon belüli vándorlását, a lakosságszám változását és korösszetételét, illetve ezek területi megoszlását. Külön foglalkoznak a külföldi állampolgárok elhelyezkedésével és a migráció hatásaival. 
A lakáshelyzet elemzése során a lakásokat különböző osztályokba sorolják, majd pedig azok térbeli megoszlását és növekedési ütemét mutatják be.

A gazdaságfejlesztéshez közvetlenül kapcsolódik a munkanélküliség, illetve a foglalkoztatás elemzése, továbbá az általános értelemben vett gazdasági fejlödés. Ez utóbbi terület mérőszáma a tartományi szinten vizsgált GDP, melyet 1965-töl 1985-ig tízéves periódusokban, ezt követöen pedig ötéves időtartam szerint értékelnek. Az aktív foglalkoztatottak növekedési arányát hasonló periódusokban, azonban már nem tartományi, hanem nemzeti szinten mutatják be. A foglalkoztatottság növekedésére vonatkozó mutatók éppúgy, mint a munkanélküliségre vonatkozó méröszámok, már tartományi szinten is rendelkezésre állnak.

A fejezet további részében az ágazati szerkezetváltozásokkal foglalkoznak. Az egyes ágazatokat (mezö- és erdögazdaság, bányászat, energia és vízellátás, ingatlan és szolgáltatási szektor, közigazgatás stb.) az ott foglalkoztatottak száma szerint hasonlítják össze. (Nem esik szó az egyes ágazatok GDP-ben való részesedéséröl, ami esetleg az adott ágazat technológiai fejlettségére is utalhat.) Eszerint a legtöbb ágazatban 1995-1997 közötti idöszakban csökkent a foglalkoztatottak száma, csupán öt ágazatban történt pozitív változás (közigazgatás, oktatás, egészségügyi és szociális szektor, ingatlan ügyek, szolgáltatások), melyek közül a szolgáltatási és ingatlanügyi szféra 10,2\%-kal gyarapodott. Külön felhívja a figyelmet a jelentés a mezőgazdaságban foglalkoztatottak számának csökkenésére (1980-1995 közötti időszak, százalékos kimutatás tartományok szerint). Hasonlóképp mutatják be az iparban foglalkoztatottak arányának csökkenését, a vizsgált időszak itt azonban 1995-töl 1998-ig terjed.

A szolgáltatási szektorban foglalkoztatottak számának általános növekedése szintén tartományi szinten kísérhetö figyelemmel, amely alól csupán két tartomány kivétel (Felsö-Ausztria és Salzburg).

A helyzetelemzés további része Ausztria szempontjából két igen fontos ágazat - a turizmus és a közlekedés - elemzésével foglalkozik. A turizmus fejlödéséröl a jelentés viszonylag szük szavúan szól, a nyári és a téli szezon vendégéjszakáinak változását bemutatva a turizmus szempontjából frekventált területeken. Sokkal nagyobb figyelmet szentelnek a közlekedésnek, ahol külön elemzik az egyes autópályák terheltségének növekedését az 1990-es és az 1997-es forgalomszámlálás adatainak alapján. Külön szólnak a személy- és teherforgalom változásáról, valamint a tömegközlekedés és a privát közlekedés viszonyáról.

$\mathrm{Az}$ imént felsorolt összes szempont igen fontos része a helyzetelemzésnek, és egyúttal alapja bármilyen típusú fejlesztési programnak. Az elemzés osztrák területfejlesztésre gyakorolt hatása csupán a különböző szinteken megjelenő területfejlesztési politika, illetve konkrét intézkedés rendszer alapján értékelhetö.

A harmadik nagy fejezet a „Területrendezési és területfejlesztési politika helyzete Ausztriában" címet viseli.

A fejezet első pontjai különböző ágazatok, illetve ágazati intézkedések egymás mellé helyezéséből tevődik össze. Ilyen ágazat, pl. a lakáspolitika, amelyen belül 
értékelik a lakásjog tovább fejlesztését, a telekjárulékok felülvizsgálatát, a magasépitések területrendezési szempontjait.

Az ágazati intézkedések között szerepel a mezőgazdaság, az erdőgazdaság, a terület-, környezet- és természetvédelem eröforrás kímélő továbbfejlesztése, az ökológiailag megfelelö vízi létesítmények kialakítása, a hegyjog területrendezésileg releváns szabályozása, a tartományi tagozódás szerinti területhasználati-hasznosítási intézkedések.

A természeti erőforrásokra vonatkozó intézkedéseket követően, a harmadik fejezeten belül - a hét alfejezet közül a negyedikként - kerül sor „A gazdaságpolitika regionális aspektusai" címủ terület ơnálló bemutatására. Az alfejezet középpontjában az uniós regionális politika, pontosabban regionális támogatások állnak. A támogatott területi egységek nem illeszkednek sem a NUTS rendszer határaihoz, sem a hagyományos tartományi határokhoz, ugyanis azok meghatározása az egyes céloknak megfelelö kritériumrendszer (GDP uniós átlaga, városias, vidékies területeken élö lakosság aránya stb.) szerint történt (6. ábra).

\section{6. ÁBRA}

\section{Az 1., 2. és $5 b$. Célkitüzésból támogatott teriiletek Ausztriában}

(The Austrian Objective 1, 2 and $5 b$ Regions)

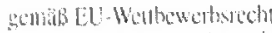

maximate Forderumsinensuit

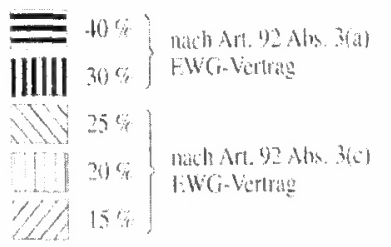

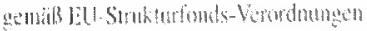

7.iel-1. (jebint

7ite. 2-(ichines

Zid 5n-Ghiste

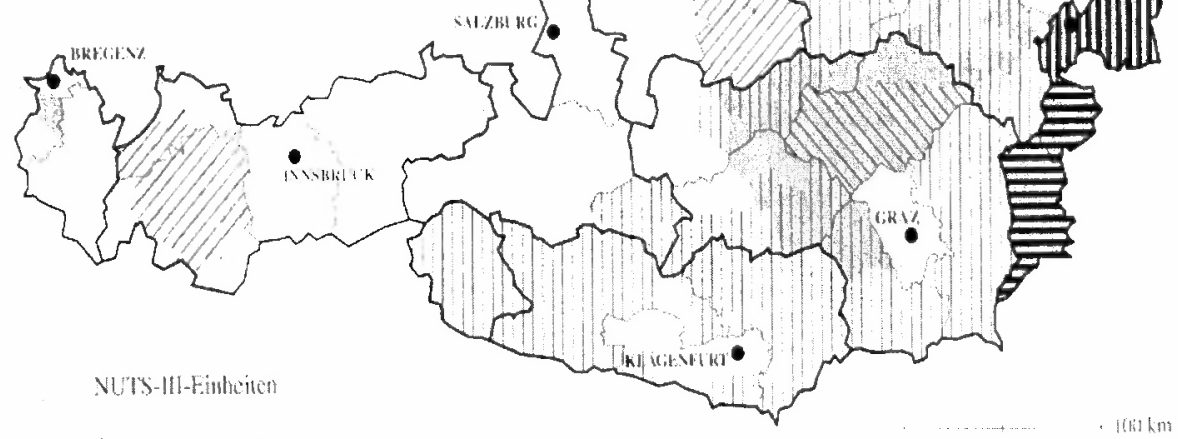

Forrás: Neunter Raumordnungsbericht 1999. 
Az egyes célok megvalósítását az alábbi arányban támogatta az EU az 1995-1999 ko̊zötti tervidőszakban (3. táblázat):

\section{TÁBLÁZAT}

A strukturális alapokból nyújtott támogatások Ausztriában

(Supports form Structural Funds in Austria)

\begin{tabular}{lc}
\hline \multicolumn{1}{c}{ Támogatás } & $\begin{array}{c}\text { Támogatás összege } \\
\text { (millió ECU) }\end{array}$ \\
\hline 1. célterület & 166 \\
2. célterület & 101 \\
3-4. célterület & 395 \\
5a célterület & 388 \\
5b célterület & 411 \\
\hline Célterületek összesen & 1,461 \\
Közösségi kezdeményezések & 146 \\
Kísérleti programok & 16 \\
\hline Teljes támogatási keret & 1,623 \\
\hline
\end{tabular}

Forrás: Neunter Raumordnungsbericht 1999.

Az egyes célterületeken belül a legtöbb regionális célprogram különbözỏ meghatározás és tagoltság szerint, az alábbi területekre helyezte a hangsúlyt:

- Ipartámogatás (az üzemeket érintö támogatás, az infrastruktúra támogatása, ipari zónák támogatása, képzési infrastruktúra támogatása);

- Kutatás és fejlesztés (technológia és innováció fejlesztés, tanácsadás és kutatás, telekommunikációs infrastruktúra támogatása, technológia-transzfer központok létrehozása);

- Turizmus (a kínálati és szervezeti struktúra javítása, kulturális turizmus támogatása, infrastruktúrafejlesztés);

- Humán erőforrások (képzés és továbbképzés, tanácsadási és minősítési intézkedések, hátrányos helyzetü csoportok bevonása a munkaerỏpiacra, felsőfokú szakképzés);

- Regionális menedzsment.

Az ipar fejlesztésére és diverzifikálására átlagosan a források 30\%-át használták fel, turizmusfejlesztésre hozzávetöleg 10\%-ot, humáneröforrás-fejlesztésre a források egyötödét, mezőgazdaságra és természetvédelemre pedig a források $40 \%$-át.

Az egyes célterületeken kívủl a regionális támogatási rendszerben nagy szerephez jutottak az egyes közösségi kezdeményezések. Ilyen többek között a hazánkat is érintő „INTERREG II A” program, melyen belül keriul sor a PHARE CBC program megvalósítására 587,4 M öS uniós támogatással (határon átnyúló együttmủködés támogatása). De a közösségi kezdeményezések közé tarozik az "INTERREG II C", 84,5 M öS uniós támogatással, a LEADER II. 363,8 M öS uniós támogatással (napjainkban a LEADER +), az URBAN program (nagyvárosi gondok - szociális ügyek, egészségügy, munkaeröpiac - javítására) 182,6 M öS uniós támogatással, valamint az ipari szerkezetátalakitást elősegíteni hivatott további négy program összesen 241 M öS uniós támogatással. 
A programok megvalósításának feltétele volt a szuiksséges adminisztratív rendszer kiépítése. A rendszer egyik legfontosabb eleme az értékelési, monitoring szervezet és eljárás kialakítása volt. A monitoring szervezet csúcsán egy külön e célra létrehozott bizottság áll, melynek tagjai az EU Bizottság képviselői, a kormányzat és tartományi kormányzatok képviselöi, a támogatást biztosító kormányzati és tartományi szervezetek képviselői, a gazdasági és szociális partnerek, valamint a város és az önkormányzati szövetségek képviselöi. Ahhoz, hogy e bizottság képes legyen a programok megvalósításának, illetve a tartalmi konzisztenciának és adminisztratív hatékonyságnak az értékelésére az egyes minisztériumok, illetve a támogatást biztosító tartományi és kormányzati szervezetek rendszeresen programspecifikus monitoring jelentéseket, valamint standardizált jelentéseket (éves jelentés) készítenek. Ezek a szervezetek nyújtanak információkat az egyes projektek költségeiröl, a felhasznált forrásokról, és az elöre tervezett eredmény indikátorokról. A bizottság adminisztratív teendőit az ÖROK látja el. Az ÖROK emellett elkészíti az EU regionális politikájának megfelelö koncepciókat és programokat, valamint az ország egészére alkalmazható területrendezési koncepciót és kialakította a tervezés alapelveit. Az ÖROK dolgozta ki 1991-ben az Osztrák Területrendezési Koncepciót, amely meghatározta a tervezés és végrehajtás irányelveit minden területi szint számára. Az ÖROK léte - 1971. óta - a kormányzat és a kormányzati partnerek (tartományok, városi és telepuilési önkormányzati szövetségek képviselói) közötti politikai egyezségnek köszönhető.

A regionális szintủ menedzsment területi szervei 8 tartományban, körülbelül 25 régióban, hozzávetőleg 40 munkatárs közremủködésével tevékenykednek különbơző szervezeti és tulajdonosi struktúra mellett. Ezeknek a fejlesztési iugynökségeknek körülbelül kétharmadát önkormányzati szövetségek hozták létre. E szervezetek legfontosabb céljai - a jelentés szerint - a következők:

- a különbözỏ aktorok és intézmények regionális szintủ fejlesztési együttmúködésének javítása,

- alulról építkező és a tartományi és szövetségi stratégiával összhangban álló stratégia kialakítása és megvalósítása,

- a regionális kulcsprojekteknek a legfontosabb regionális szereplőkkel konszenzusban történő előmozdítása (Neunter Raumordnungsbericht 1999, 95).

Ezen túl a jelentés megállapítja, hogy e szervezetek nem ágazati szaktanácsadást látnak el, nincs politikai funkciójuk, nem konkurensei a meglévő szolgáltató szervezeteknek, hanem kiegészítik azok tevékenységét. A menedzseri munka középpontjában az információszerzést, a tanácsadást és menedzselést, a projektkészítést, valamint a regionális szereplők „hálózatosodásának” fejlesztését állítják.

Az előzőekben az Európai Unió által meghatározott célokról és támogatásokról, valamint az azokat kezelő szervezetrendszer felépítéséről és múködéséről esett szó. A jelentés a továbbiakban nemzeti szinten meghatározott regionális fejlesztési programokkal foglalkozik, igaz, azokat a belépést követően hozzáigazították az uniós követelményekhez, annak érdekében, hogy a megvalósításukhoz uniós forrásokat is felhasználhassanak. 
Ilyen program például az ipar- és gazdaságfejlesztés támogatása (RIP) a nyolcvanas évektől kezdődően, majd 1996-tól a regionális infrastruktúra támogatása (RIF), a TOP turizmus támogatása 1997-tól, de külön érdemes kiemelni az 1994-től kezdődő, önálló regionális fejlesztés támogatását célzó akciót. E program keretében támogatták a regionális együttmủködési struktúrák kialakítását (regionális célokat megfogalmazó önkormányzati és ágazaton túlnyúló szövetségek alapítása és szervezeti fejlesztése), regionális - beleértve a kisregionális - koncepciók készítését, regionális projektek készítését (beleértve a megvalósítás támogatását is), végül pedig a regionális menedzsment létesítését az egyes tartományokban. A 4. táblázat a vázolt program eredményeit kívánja bemutatni.

\section{TÁBLÁZAT}

„Támogatási akció az önálló regionális fejlesztésért 1996-1998" (millió öS)

(Support Action for the Autonomic Regional Development 1996-1998)

\begin{tabular}{|c|c|c|c|c|c|c|}
\hline & \multicolumn{3}{|c|}{ Regionális menedzsment } & \multicolumn{3}{|c|}{ Projekt tanácsadás } \\
\hline & $\begin{array}{l}\text { Szerveze- } \\
\text { tek száma }\end{array}$ & $\begin{array}{l}\text { Támoga- } \\
\text { tott pro- } \\
\text { jekt költ- } \\
\text { ségek }\end{array}$ & $\begin{array}{c}\text { Támogatás } \\
\text { nagysága }\end{array}$ & $\begin{array}{c}\text { Projektek } \\
\text { száma }\end{array}$ & $\begin{array}{l}\text { Támoga- } \\
\text { tott projekt } \\
\text { költségek }\end{array}$ & $\begin{array}{c}\text { Támogatás } \\
\text { nagysága }\end{array}$ \\
\hline Ausztria & 25 & 198,6 & $\begin{array}{c}\mathrm{BKA}^{*}: \\
26,6 \\
\text { EFRE }^{* *}: \\
22,8\end{array}$ & 59 & 44,2 & $\begin{array}{c}\text { BKA }^{*}: \\
14,6 \\
\text { EFRE }^{* *}: \\
9,3 \\
\end{array}$ \\
\hline Tartományok & \multicolumn{6}{|c|}{ részesedése } \\
\hline Burgenland & 1 & & & 0 & & \\
\hline Karintia & 3 & & & 11 & & \\
\hline $\begin{array}{l}\text { Alsó- } \\
\text { Ausztria }\end{array}$ & 4 & & & 13 & & \\
\hline $\begin{array}{l}\text { Felsö- } \\
\text { Ausztria }\end{array}$ & 3 & & & 7 & & \\
\hline Salzburg & 3 & & & 4 & & \\
\hline Steiermark & 6 & & & 19 & & \\
\hline Tirol & 4 & & & 3 & & \\
\hline Voralberg & 1 & & & 2 & & \\
\hline
\end{tabular}

*BKA: Miniszterelnöki Hivatal, **EFRE Európai Regionális Alap

Forrás: Neunter Raumordnungsbericht 1999, 97. o.

A jelentés hangsúlyozottan foglalkozik a nemzeti innovációs és technológia politikával, ahol az eredményeket az érintett szereplók és területek megjelölésével, a projektek számáva! (185) és a támogatási összeggel ( $870 \mathrm{M}$ öS) jelölik. Az agrár támogatási program esetén az agrárhitelek és a hátrányos helyzetú területek támogatására fordított összegek jelentették az értékelés szempontjait.

A jelentés a regionális politikán belül helyezi el a munkaerő-politikát, mely - az elemzés terjedelme alapján - annak egyik legjelentősebb részét képezi. A munkaerő-politika támogatása kizárólag nemzeti forrásból történik, melynek megfelelően külön nemzeti tervet dolgoztak ki a foglalkozatási helyzet javítására, aminek célja o̊t éves perióduson belül a munkanélkülliségi ráta 3,5\%-os szintjének megközelítése. A jelentés emellett összefoglalja az 1998-ra vonatkozó munkaerỏ-politika stratégiai 
célkitüzéseit is. Külön esik szó a magyar értelemben vett munkaügyi központok tevékenységéröl, amelyet - hazai gyakorlathoz hasonlóan - a tartós, a 45 év feletti munkanélküliek számával, az újra munkába állók arányával stb. jellemeznek. Ezen túl bemutatják az aktív és a passzív munkaerö-politikai eszközökre költött összegek nagyságát, illetve azok arányát az összes munkaügyi költségen belül. Az elemzések befejezésével együtt befejeződik a regionális politikával foglalkozó rész is, hogy aztán ismét visszazökkenjünk az egyes ágazatokat bemutató értékelések világába.

A jelentés a soron következő ágazatok közül a közlekedéspolitikával foglalkozik, majd pedig a területileg releváns egyéb infrastruktúrák bemutatására kerül sor. A fejezet - fentiekben ismertetett - 1. pontjának utolsó részében esik szó a területrendezés információs alapjairól. A területi információk gyủjtéséről és feldolgozásáról az Osztrák Területtervezési Intézet gondoskodik, amely 1996-tól éves jelentéseket készít a NUTS 3 régiókról. A feldolgozás alapjául szolgáló adatok viszont járási szinten is rendelkezésre állnak. Az adatokhoz való hozzáférés megkönnyítése érdekében ez az intézet létre hozta az ún. regionális információszolgáltatási statisztikát, amely a legfontosabb átfogó adatokkal szolgál az egyes régiók demográfiai, gazdasági és szociális helyzetéröl.

A jelentés következö része - továbbra is a harmadik fejezeten belül - a tartományok és a nagyobb városok területrendezéssel kapcsolatos tevékenységét, illetve területrendezési programjait ismerteti. Az egyes tartományi programok összefoglaló bemutatása előtt, a jelentésben a területi szint feletti tervezés jogi alapjairól esik szó, melyet a korábbiakban már ismertettünk. Az alábbiakban az egyes tartományok tevékenységének - jelentéssel megegyező - rövid elemzésére kerül sor.

Burgenland beszámolójában az új burgenlandi építésügyi jogra, a határon átnyúló közúti forgalom problémáira helyezi a hangsúlyt. Emellett rövid áttekintést nyújt több kistérség - elsősorban turizmusfejlesztési - koncepciójáról is.

Karintia bemutatja „Karintia fejlesztési jövöképét” a területi ágazati fejlesztési programokból. E tartományban - a beszámoló szerint - különleges figyelmet fordítanak az EU regionális politikájának megvalósítására.

Alsó-Ausztria beszámol az 1996-os építési szabályzat átdolgozásáról, a szektorális tartományi területrendezésröl, az átfogó közlekedési ügyekről és a területét érintő uniós programokról. A regionális tervezés Alsó-Ausztriában lényegében a regionális területrendezési programokra és a kisrégiós fejlesztési koncepciókra terjed ki. További központi témát jelent a helyi tervezés, a falu és városfelújítás.

Felső-Ausztria bemutatja a tartományi területrendezési törvény 1997-es módosításait, a tartomány által fontosnak tartott területi kutatásokat (közlekedési kutatások, terület használatra vonatkozó kutatások), továbbá a Felső-Ausztriában folyó uniós programokat. 1998-ban elkészítették a tartomány területrendezési programját, amely az ellátási feladatok alapján 4 kategóriát határoz meg: regionális szint feletti centrumok, regionális központok a vidéki területeken, centrális helyek a város környéki területeken és a kisközpontok. A települések regionális tervezésbe történő bevonását regionális tervezési tanácsok segítségével kívánják elősegíteni. Ezideig 
7 ilyen tanácsot állítottak fel (a részt vevö önkormányzatok száma 4 és 17 között mozog), további három felállításán pedig dolgoznak.

Salzburg beszámolója kitér az 1997-es területrendezési törvény módosítására, mely alapján a tervezési kompetencia tartományra történő átruházását biztosítja, valamint a területhasznosítási tervek területrendezési törvényhez történö igazítására.

Stájerországban új szempontok szerint határozták meg a központi helyeket (oktatási funkció, szociális, szolgáltatási funkció stb.). A tartomány szerint az ún. részleges regionális fejlesztési jövőképek hivatottak elösegíteni a településpolitikai és a telephelyekre vonatkozó kérdések megoldását. Az uniós programok zökkenőmentesebb megvalósítása érdekében regionális menedzsment irodákat hoztak létre, és regionális fejlesztési jövöképeket alakítottak ki. A területrendezési szempontbó] fontos ágazati programok között a jelentés az „Aichfeldi lápos talajú szabad térségi koncepció"-t emeli ki.

Tirol beszámolójában szerepel az új, 1997-es területrendezési törvény, a helyi és a helyi szint feletti koncepciókra vonatkozó szabályozás, valamint egyes ágazati koncepciók és programok, mindenekelött azonban Tirol gazdasági jövőképe.

Voralberg 1997-ben készítette el a területi tervezési törvényét, amelyben különös figyelmet szentelnek a településfejlesztésnek, valamint a beépítetlen területek fenntartásának a Rajna-völgyben és Walgauban. A kiskereskedelemben jelentkező koncentrációs tendenciák negatív hatásait különbözö formákban igyekeznek minimalizálni.

Bécs beszámol a „Bécs 2000 stratégiai terv” megkezdett munkáiról, az európai várospolitika keretében megvalósuló kiemelt uniós projektekről (elsősorban az URBAN programról), valamint a várostervezés és -fejlesztés megvalósított fontosabb kérdéseiről, mint például a bécsi bevásárló utcák vonzóbbá tétele, a bécsi vásárlóerő áramlás vagy az irodaház fejlesztés. A bécsi jelentés kitér olyan problémákra is, mint a zöldövezeti tervezés, a szabad területek biztosítása, közlekedéstervezés, tudomány és kutatástámogatás, valamint PR tevékenység.

A tartományi beszámolókat egyes ausztriai nagyvárosok jelentései követik, amelyek a települési fejlesztésekről és elképzelésekrỏl szólnak.

A negyedik fejezet a nemzetközi, illetve a határon átnyúló együttmúködésekkel foglalkozik, az ötödik - és egyben utolsó - fejezet az ÖROK tevékenységét foglalja össze.

\section{Következtetések}

Az osztrák területfejlesztési és értékelési rendszer áttekintését követően felvetődik a kérdés, hogy a bemutatott ismeretek, a szomszédunkban meghonosított módszerek, mennyiben járulhatnak hozzá a magyar területfejlesztés továbbfejlesztéséhez, az értékelési gyakorlat kialakításához.

Álláspontunk szerint az egyes ágazati politikák és értékelések egyszerü egymás mellé állítása nem a területfejlesztési politika értékelését jelenti. Abban az esetben, ha nincs egy olyan - lehetőleg területi szinten megjelenö - átfogó cél, mint például 
a gazdaságfejlesztés, amely egyúttal koordinatív funkciót tölt be az egyes ágazati elképzelések között, és amelyre való tekintettel valósul meg az összes ágazatot érintő fejlesztés, akkor csupán ágazati fejlesztésről beszélhetünk, ami természetszerüleg nem azonos a területfejlesztéssel. Ebben a rendszerben a területfejlesztés maga is csupán egy ágazat, amely integratív funkcióját ilyenformán nem töltheti be.

Problémát jelent az osztrák rendszerben az is, hogy valódi területfejlesztési politika - nemzeti kezdeményezés alapján - csak szövetségi szinten létezik, ott is meglehetösen szük területen. Területfejlesztés területi egységekre történö lebontás nélkül ugyan létezhet, azonban annak hatékonysága - melyet például az alulról felfelé építkezés elve kíván kifejezni - messze elmaradhat a különbözö területi szintek által készített és megvalósított területfejlesztési programoktól, projektektől. Abban az esetben pedig, ha az ágazati politika domináns a területi politikával szemben, a területi egységek önálló fejlesztési szempontja jelentősen háttérbe szorulhat az adott ágazat nemzeti szintet alapul vevő fejlesztési elképzelései mellett. Ez ismét az egyes területek fejlettségi különbségeinek kiegyenlítése ellen hathat.

Az Ausztriát bemutató jelentés alapján úgy tủnik, hogy - a tartományok számára jelentős döntési jogosítványokat biztosító szövetségi berendezkedés ellenére - a területfejlesztés rendkívül csekély mértékben jelenik meg azon a szinten, ahol a legerősebbnek kellene lennie, vagyis a tartományok szintjén.

A területfejlesztés primer forrása kisebb részben a nemzeti, meghatározó mértékben az Unió területfejlesztési támogatási rendszere.

Mindezekre tekintettel felmerül a kérdés, hogy követve az osztrák példát, kényelmesen elhelyezkedve a karosszékben megvárjuk a strukturális alapok támogatási rendszerének hazai bevezetését, ahol meglehetỏsen szabályozott formában egy meghatározott pálya és mozgástér mellett adaptáljuk az előre meghatározott cél- és értékelési rendszert, vagy pedig innovatív módon tovább dolgozunk az egyes területi fejlesztési lehetőségek kialakításán. Kérdés az is, hogy értékelési rendszerünk mennyiben legyen program alapú (beleértve a hazai programokat is), mennyire legyen ágazati központú, milyen szerepet játszanak abban a területfejlesztésre vonatkozó jogszabályok, pontosabban az azokban meghatározott célok és elosztási szempontok.

Amennyiben komolyan vesszük a területfejlesztés gazdaságfejlesztésben betöltött szerepét, akkor e kérdések megválaszolása - elsődlegesen a döntéshozók részéről nem kerülhető meg.

\section{Jegyzet}

'A tanulmány része az MTA RKK és az FVM közötti, az „EU csatlakozás, Regionális politika, Terủletfejlesztés" tárgykörében kötött szerzödés keretében teljesített munkának. 


\section{Irodalom}

Hesina, W.-Knoflacher, M.-Wagner, P.-Lechner, F.-Bergmann, N.-Pfefferkorn, W.-Resch, A. (2002) ExPost-Evaluierung der Ziel 56 und LEADER II Programme 1995-1999 in Österreich. ÖROK, Wien.

Neunter Raumordnungsbericht. (1999) ÖROK, Wien.

Semsroth, K.-Dillinger, T. (2002) Föderalaes Planen - der Reichtum der Inkonsistenz. DISP, Wien.

Schindegger, F. (1999) Raum, Planung, Politik. Böhlau, Wien, Köln, Weimar.

Thierstein, A. (2002) Von der Raumordnung zum Raumentwicklung. DISP, Wien.

Zehetner, F. (2001) Deutsch-Österreuches Handbuch der Planungsbegriffe. ÖROK, Wien. 